\title{
Characteristics of Discussion in "Public Sphere" of Vietnam Electronic Newspaper through "News and Opinion" Column - Tuoi Tre Newspaper*
}

\author{
Phan Van Kien \\ University of Social Sciences and Humanities, Hanoi National University, Vietnam
}

Copyright $\mathrm{O} 2018$ by authors, all rights reserved. Authors agree that this article remains permanently open access under the terms of the Creative Commons Attribution License 4.0 International License

\begin{abstract}
By analyzing the characteristics of the discussion process in the Vietnamese electronic newspaper's space through a survey of a column on Tuoi Tre Newspaper will illustrate four basic characteristics of the discussion on electronic newspapers: 1/ Characteristics of a "virtual sphere"; 2 / personal identity of the discussants; 3 / limits of discussion; 4 / leadership of Leader Opinion. From this analysis, the article will discuss more the levels of discussion, the limits of the discussion process in public sphere of electronic newspapers in Vietnam.
\end{abstract}

Keywords Public Sphere, Feedback, Vietnamese Electronic Newspapers, Tuoi Tre Newspaper

\section{Introduction}

The concept of "public sphere" was referred by Jurgen Habermas in 1962 by developing Emmanuel Kant's concept in 1784. In the world as in Vietnam, many authors have studied this concept from different perspectives such as Papacharissi [1, 2], Jones [3], McChesney [4], Poster [5], Carey [6], Fallows [7], Tran Huu Quang [8], Nguyen Quy Thanh et al [9], Phan Van Kien [10], Nguyen Thi Thuy Hang et al [11].

When defining "enlightenment" as "liberation from a self-imposed or at least tolerated childishness," 18th-century German philosopher Immanuel Kant emphasized that "one must always be free to use his or her own reasoning, and only this can bring about the enlightenment of man" [12]. Discussing the role of social reaction, Kant states: "This can only happen through public space if a nation wants to express its grievances. The ban on public space, therefore, will hinder the advancement of a nation towards the better." [13]. According to Kant, one can only face one's self by speaking only in the monologue. Only when their voices are communicated, argued with others about public affairs can we avoid the self-imposed.

From Kant's concept, Habermas has developed into the theory called Public Sphere. "According to Habermas, the public sphere is a space in which any individual can engage and exchange ideas without external pressure. In this principle, this is the place where rational-critical debates take place, and thus this is the place where the opinions (public opinion) and the will of the public are expressed. The rational nature of dialogue in public space helps one to move beyond specific interests to reach a consensus among good persons. In medieval society, there was no public sphere in this sense; it appeared only in modern times in capitalist society as a counterbalance to prevent authoritarian powers. [8]

US sociologist Daniel Lerner, in a post in the Journal of Behavioral Science, October 1957, suggested that one typical condition and characteristic in the transition from traditional societies to modern societies is the transition from oral communication systems to mass communication [19].

According to Lerner, the ability to read and write helps human beings to develop psychic flexibility (psychic mobility), which are a feature of mankind in modern society. Mass media is the most powerful contributor to empathy as well as intellectual agility, as they help people to come up with a variety of ideas and to know the public issues of society.

"The emergence of the Internet in the last few decades has raised a number of new issues related to mass media in modern society. In a book published in 2004, Serge Soudoplatoff stated that the history of Internet media corresponds to the clash between management and Governance. On the one hand is a centralized approach, modeled on a hierarchy, and on the other hand, spread out as networks connecting people with similar interests or interests. According to Soudoplatoff, the amazing success of the Internet suggests that one can have more effective governance models than traditional models based on 
hierarchical levels: the logic of the Internet is to share powers. It is an interactive tool and a transaction between positive and equal actors, not between a broadcasting center and a passive audience like in the TV media". [8]

In Habermas's work "The Structural Transformation of the Public Sphere", the three criteria called "institutional standards" are mentioned as a prerequisite for the emergence of a new public sector. Public sites such as the British cafes, French beauty parlors or German restaurants "may vary in size and composition, the style of the discussion, the atmosphere of the debate, topic and subject matter" but "all discussions among people tend to continue, so they have some common institutional standards". That is:

1. Ignorance of social status

2. Field of interest discussion

3. Limit of participation [14].

Some of the concepts of public sphere have been referred to as "Semi-public space" by Nguyen Quy Thanh et al. [9], "Private space-Zizi Papacharissi [2]". In particular, when the internet came into being along with the development of social networks, the concept of public sphere became more abundant and complex than the original concept. The internet has become a particular form of virtual space - a virtual sphere [1]. In this sphere, public participates in social discussion processes under the leadership of "leader opinions" such as journalists - a form of community activity that has been created to form public discourse.

In Vietnam, the concept of the public sphere is often referred in terms of architecture, planning and urban management. From the perspective of social science, Nguyen Quy Thanh et al. [9], Do Van Quan [15], Nguyen Thi Bich Thuy [16], Nguyen Thi Thuy Hang et al. [11]... The concept is emphasized in the sociological and politic approach; public sphere is a place to form the social opinion and political expression.

This article, by examining reader's reaction on a specific column "News and Opinion" in Tuoi Tre Newspaper, we consider the electronic space is a specific "public sphere" where social discussions can take place very clearly with reader's feedback. However, due to the characteristics of Vietnam's press and environment, this discussion in the public space has very different characteristics from the types of public spaces that were previously approached.

\section{Encoding Survey Data}

By examining the 353 articles in Column "News and Opinion" in Tuoi Tre Newspaper in October 2016, we divided the main content of these articles into seven topics: politics (1), society (2), economics (3), education (4), health (5), sports (6), culture (7). This division is only relative to make the analysis process more specific. In fact, there are some articles that mention different themes. Therefore, we temporarily put those articles into the theme that are main or more explicit in article's content.

For the reader's opinion, they are divided into five trends according to the following table:

Table 1. The classification of readers' opinion in "News and Opinion" of Tuoi Tre Newspaper, 10/2016

\begin{tabular}{|c|c|c|}
\hline Code & Tendency & Illustration \\
\hline 1 & Supporting the article's viewpoints & $\begin{array}{c}\text { Expressing supportive viewpoint with the articles, sympathy for the character in } \\
\text { difficult situation in the article }\end{array}$ \\
\hline 2 & Providing more information and new perspectives & $\begin{array}{c}\text { Expressing Ironic, critical attitude of the wrongs, unethical, non-cultural } \\
\text { phenomena. }\end{array}$ \\
\hline 3 & Emphasizing personal perspective & $\begin{array}{c}\text { Expressing personal views, these are the opinions and views of the reader after } \\
\text { reading the article, the attitude of the reader, proposing a solution, or sharing } \\
\text { similar experience the reader has. }\end{array}$ \\
\hline 4 & $\begin{array}{c}\text { Emphasizing on the transition from comment to } \\
\text { calling for action }\end{array}$ & Supporting, encouraging the author, calling for action ... \\
\hline 5 & Others & $\begin{array}{c}\text { Respecting and blessings for the author, } \\
\text { Comments that are not relevant to the topic or not constructive in the discussion. }\end{array}$ \\
\hline
\end{tabular}

During the survey, the author also encountered difficulties in delineating each discussion. There are comments that are both supporting and criticizing the article's viewpoints, condemning the negative action and proposing possible solutions. There are comments expressing support for the viewpoint of the author but in essence, expressing the criticism and condemnation. In addition, there are comments that are the interactions between the reader and the article, while some that are the interactions between readers and readers. Therefore, we have considered and ranked the comments according to the criteria set by the author. 


\section{Electronic Newspapers - Special "Public Sphere" for Social Discussion}

In many studies, the authors, though in different directions share the similar view that the emergence of the internet in the modern society has awakened the previously forgotten concept about the public sphere.

"Proponents of cyberspace promise that online discourse will increase political participation and pave the way for a democratic utopia. According to them, the alleged decline of the public sphere lamented by academics, politics, and several members of the public will be halted by the democratizing effects of the internet and its surrounding technologies. On the other hand, skeptics caution that technologies not universally accessible and ones that frequently induce fragmented, nonsensical, and enraged discussion, otherwise known as 'flaming', far from guarantee a revived public sphere" [1].

Dewey [17] argues that the need for information and communication is the foundation of a democratic society. He emphasized the results of group discussions rather than the decisions made by a competent individual. He supported a democracy where all members of society and where individuals meet to create and maintain a common good life. The term "public" implies the idea of citizenship, in a universal understanding, and the public rights that everyone can access and observe.

Jones argues that internet space is seen as a "new public sphere" created by humans and linking the ideas of progress with the strong momentum of modernity towards self-fulfillment, personal development and human development [3: 7].

In his work, Jurgen Habermas listed the characteristics of freedom and equality needed for an ideal discussion [14] in a democratic society. However, members of the public sphere also must respect certain rules of "ideal speech situations." Those are:

1. Every subject who has the knowledge (ability) to speak and act is allowed to participate in the discussion.

2. Everybody is identified, discuss issues, and express their attitudes, wants and needs.

3. No speaker is prevented from exercising their rights as set out in mentioned in Part1 1 and 2, by any internal or external pressures.

Although the participants in the public sphere are free, regardless of social status, there is still a screening. Habermas noted that not all the public but only a small part participates in social discussion processes.

Discussing the relationship between media and the public sphere, Jurgen Habermas says, "The media is especially important for building and maintaining a public space. Media is as actors in public politics. "According to Habermas, "There are two types of actors that without them, no public politics can work: experts in communications systems and experts in politics." [18].

The media (in which the press is the main force), "is no longer the narrow ground for the media, but the mass media is the place where the information, the knowledge and the place relations, contacts, communication between groups, social classes " [18].

According to Habermas, the media itself is the most typical institution in the public sphere. They serve as intermediaries for communication and interaction within the civil society and state institutions.

Newspapers in addition to the basic features have been proposed by Habermas as above, the discussion process on the electronic also have their own characteristics.

First, it's a virtual space. Individuals who participate in internet forums in general and electronic newspapers, in particular, are identified as nicknames. Because of the virtuality of this space, self-responsibility is not guaranteed.

Secondly, although participating in a public sphere, the members involved in the discussion are separate individuals (with each computer connected to their own internet). So, discussion content is public space, but discussion space is still personal. This feature makes the sociality of the less dramatic than direct focus in a real space.

Thirdly, the discussion content is broad but is essentially limited to a topic originally proposed. That is to say, the focus on opinions is emphasized.

Fourthly, though it is a public forum, the space discussed in the electronic newspaper is always led by a "leader opinion" by one or more oriented articles with the former basic information. The leader is the journalist. Discussions on the electronic forum always start with one or more posts by reporters, and then the editorial board will continue to open forums for readers to comment. Moreover, no public feedback was posted on the electronic media during the discussion. There was always a section controlling this discussion process so that they would not go beyond the allowed limits. This feature shows that public space on electronic newspapers is an open space with orientation [10]

\section{Survey Results of "News and Opinion" in Tuoi Tre Online from October 2015 to October 2016}

\subsection{Level of Public Interest with the Article Topics}

With an online newspaper, the level of public interest is measured by three basic factors: the number of readers, likes, and comments. In this series, we use the two elements that are directly measured on the interface: like and comment to assess the level of interest of the public with the articles in the column "News and Opinion" in Tuoi Tre newspaper.

The number of like for each topic is not proportional to 
the number of posts on that topic. The rankings are: Society (116,144 likes), Politics (86,083 likes), Economics (34,826 likes), Education (32,291 likes), Culture (23,382 likes), Health (19,042 likes), Sports (2,167 likes).

This order changes compared with the number of posts. Society, Politics, and Economics articles still hold the highest number, sports articles still have the lowest number of like, but the articles in the field of culture are significantly in the number of posts.

The number of readers commenting on articles with society topic is the highest with 1832 comments, accounting for $43.42 \%$; Politics articles ranked second with 673 comments, accounting for $15.96 \%$; ranked third with 572 views and accounting for $13.56 \%$ is Business articles. Articles about Culture, Education, Health, and Sport ranked at lower positions respectively.

By comparing the number of posts in each topic, likes and comments, we can see that the rank order does not change. The top three are Society, Politics, Economics, and the lowest are Sports. However, these results have not yet been able to assess the trend of readers 'interest in the article and the trend of readers' comments on the field.

From examining each sector in detail, it can be seen that the three topics Society, politics, economics still account for the largest amount of like and comment because these are three areas of information relevant to the daily life of the public (policy, life, and living standard). Other arrays are also relevant but are more narrowly specialized. This result reflects the actual nature of the public on electronic newspapers, although the public sphere here is characterized by virtual space.

For likes and comments (see Table 3), Education and Politics hold the highest ratio of like (1,700 and 1,411 like). This reflects the nature of the public discussion that Habermas has noted that discourses and political discussions often attract the attention of many participants. In addition, Health and Education topics have a high rate of like/article because of the number of posts on these topics.

For percentage of comments/article, although the rates of like/ article are clearly variant among different topics, the comment rate does not show a considerable difference. This can be explained by two reasons: First, political issues are considered as "sensitive" and therefore comments are more strictly censored by editorial boards. Second, the large number of posts in Economics, Politics, and Society should affect the rate of comments. This result does not necessarily reflect the public's interest or concern with each sector.

Table 2. Survey results on the number of posts, likes, comments divided by theme

\begin{tabular}{|c|c|c|c|c|c|c|c|}
\hline \multirow{2}{*}{ NO } & \multirow{2}{*}{ Topic } & \multicolumn{2}{|c|}{ Article } & \multicolumn{2}{c|}{ Like } & \multicolumn{2}{c|}{ Comment } \\
\cline { 3 - 8 } & & Quantity & Percentage (\%) & Quantity & Percentage (\%) & Quantity & Percentage (\%) \\
\hline 1 & Politics & 61 & 17.28 & 86083 & 27.42 & 673 & 15.96 \\
\hline 2 & Society & 150 & 42.49 & 116144 & 37.00 & 1832 & 43.43 \\
\hline 3 & Economics & 56 & 15.86 & 34826 & 11.09 & 572 & 13.56 \\
\hline 4 & Education & 19 & 5.38 & 32291 & 10.29 & 352 & 8.35 \\
\hline 5 & Health & 18 & 5.10 & 19042 & 6.07 & 187 & 4.43 \\
\hline 6 & Sports & 3 & 0.85 & 2167 & 0.69 & 69 & 1.64 \\
\hline 7 & Culture & 46 & 13.03 & 23351 & 7.44 & 533 & 12.64 \\
\hline
\end{tabular}

Table 3. Number of likes and comments per topic

\begin{tabular}{|c|c|c|c|c|c|}
\hline Topic & Number of articles & Likes & Comments & $\begin{array}{c}\text { Average number of likes } \\
\text { per article }\end{array}$ & $\begin{array}{c}\text { Average number of } \\
\text { comments per article }\end{array}$ \\
\hline Politics & 61 & 86083 & 673 & 1411 & 11 \\
\hline Society & 150 & 116144 & 1832 & 774 & 12 \\
\hline Economics & 56 & 34826 & 572 & 622 & 10 \\
\hline Education & 19 & 32291 & 352 & 1700 & 19 \\
\hline Health & 18 & 19042 & 187 & 1058 & 10 \\
\hline Sports & 3 & 2167 & 69 & 722 & 23 \\
\hline Culture & 46 & 23351 & 533 & 508 & 12 \\
\hline
\end{tabular}




\subsection{Readers' Opinions on Public Sphere of Electronic Newspaper}

Table 4. Statistic of readers' comment trend

\begin{tabular}{|c|c|c|c|}
\hline NO & Comment trends & $\begin{array}{c}\text { Number of } \\
\text { comments }\end{array}$ & Ratio \\
\hline 1 & Supporting the article's viewpoints & 863 & 20.46 \\
\hline 2 & $\begin{array}{c}\text { Providing more information and } \\
\text { new perspectives }\end{array}$ & 382 & 9.06 \\
\hline 3 & Emphasizing personal perspective & 2542 & 60.27 \\
\hline 4 & $\begin{array}{c}\text { Emphasizing on the transition from } \\
\text { comment to calling for action }\end{array}$ & 387 & 9.17 \\
\hline 5 & Others & 62 & 1.47 \\
\hline
\end{tabular}

Survey result has revealed that personal perspective is by far the most dominant type of comments. These personal opinions include readers' opinions, attitudes, the proposition of solution, or the personal experiences of readers in relation to the content of the article.

This rate is consistent with the second characteristic of the discussion process on the public sphere of the electronic newspaper we have stated above. In a public sphere but in essence a virtual gathering of separate individuals using separate discussion devices (computers, phones ...), so the space discussed here is actually personal space. This characteristic of the public sphere in electronic newspapers has made the discussion more personal, i.e, the social aspect is dramatically reduced as ethical norms are blotted out when the individuals in the discussion do not have to face each other in a real space.
For example, in the article "Who will answer for the Vietnamese people this bitter question?" by the author Da Ngan (November 17, 2015), there are straightforward comments like that of reader "Quoc thang": "What the point of learning only the victories in history, we also need to learn the ups and downs of our father's country to remind the next generation to understand how we created a unified nation like today, how many generations have fought and sacrificed."

Or reader Khai Chi told his personal experience: "When I was in the late $80 \mathrm{~s}$, most of my history lessons were listening to the passionate retelling of history from my teacher, from military campaigns in the late feudal period to the War against American Invasion and international history from World War I to World War II. How Napoleon and Hitler rose and fell". Soon after, reader Khang discussed "I am a teacher of the secondary school. Students love teaching that way but my superiors ignored it because it does not "stick to official manual", not "sticking to standard knowledge skills", the class "not satisfactory", if the lesson conformed to proper standard, the students kept yawning and yawning but somehow the lesson still received "positions standard". I gave up."

Thus, it is safe to assume that personal touch is a clear feature of comments on the public sphere of the electronic newspaper.

To be more specific, we outline the statistic of comments according to comment trends on each topic. The result is shown in Table 5:

Table 5. Ranking of comment ratio (\%) for each topic

\begin{tabular}{|c|c|c|c|c|c|c|c|}
\hline & Politic & Society & Economic & Education & Health & Sports & Culture \\
\hline Trend 1 & 22.44 & 19.87 & 18.88 & 24.15 & 20.86 & 2.90 & 21.39 \\
\hline Trend 2 & 10.55 & 8.84 & 8.04 & 3.98 & 10.70 & 10.14 & 11.63 \\
\hline Trend 3 & 53.05 & 62.94 & 64.69 & 60.51 & 66.84 & 69.57 & 51.78 \\
\hline Trend 4 & 10.85 & 7.59 & 7.17 & 9.94 & 1.60 & 17.39 & 12.38 \\
\hline Trend 5 & 3.12 & 0.76 & 1.22 & 1.42 & 0.00 & 0.00 & 2.81 \\
\hline
\end{tabular}

The results of the survey in Table 5 still confirm the strength of personal perspective in discussing in public sphere of electronic newspaper with the ratio of all seven topics remains above 50\%. However, there are differences among different topics. According to the results of the survey, the sports sector has the highest personal opinion rating of $69.57 \%$. Readers show the lowest numbers of personal opinion on the political and cultural sectors, with a $53.05 \%$ and $51.78 \%$ rate respectively. In the areas of health, economics, society, and education, the percentages of personal opinion reflected in comments are $66.84 \%, 64.69 \%, 62.94 \% 60.51 \%$, in that order.

The trend to increase information and opinions remains high in the culture at the rate of $11.63 \%$. Health sector ranks second with $10.7 \%$. It is noticeable that readers tend to comment to criticize in the field of politics and sports with an average rate of $10.55 \%$ and $10.14 \%$, respectively. This result is consistent with the results analyzed in Table 3 where the political sector has a large number of articles and likes, but the number of comment per article is low because of the "sensitivity" of the field.

Because of its sensitivity, the editorial office also controls the comments quite closely: "People who monitor online content will be responsible for handling and controlling readers' comments. We have a dedicated staff to oversee this task. The author does not participate in the discussion process with the readers because after the post was published, it was owned by the newspaper. Authors who want to participate in the discussion process with readers can sign in with another account, participating as a reader to comment. Not all of the readers' comments are available to the public; comments with offensive languages or violating the newspaper's principle will not be published" (in-depth interview with the editorial secretary of Tuoi Tre newspaper). 


\subsection{Analyze Several Typical Cases}

First, We analyze readers' opinions in the article "Who will answer for the Vietnamese people this bitter question?" by the author Da Ngan posted on November 17, 2015. This article has received the highest number of likes (25000 likes) and comments (158 comments).

Talking about keeping or dropping history in the school curriculum, the author writes: "We have lost so many things and now are we going to lose history in our school too? Why is this happening, Who will answer for the Vietnamese people this bitter question?".

The article attracted 158 comments. Outstanding comments reached over 600 likes. The article is discussed, argued and opens up several related issues. Here are some of the most popular comments.

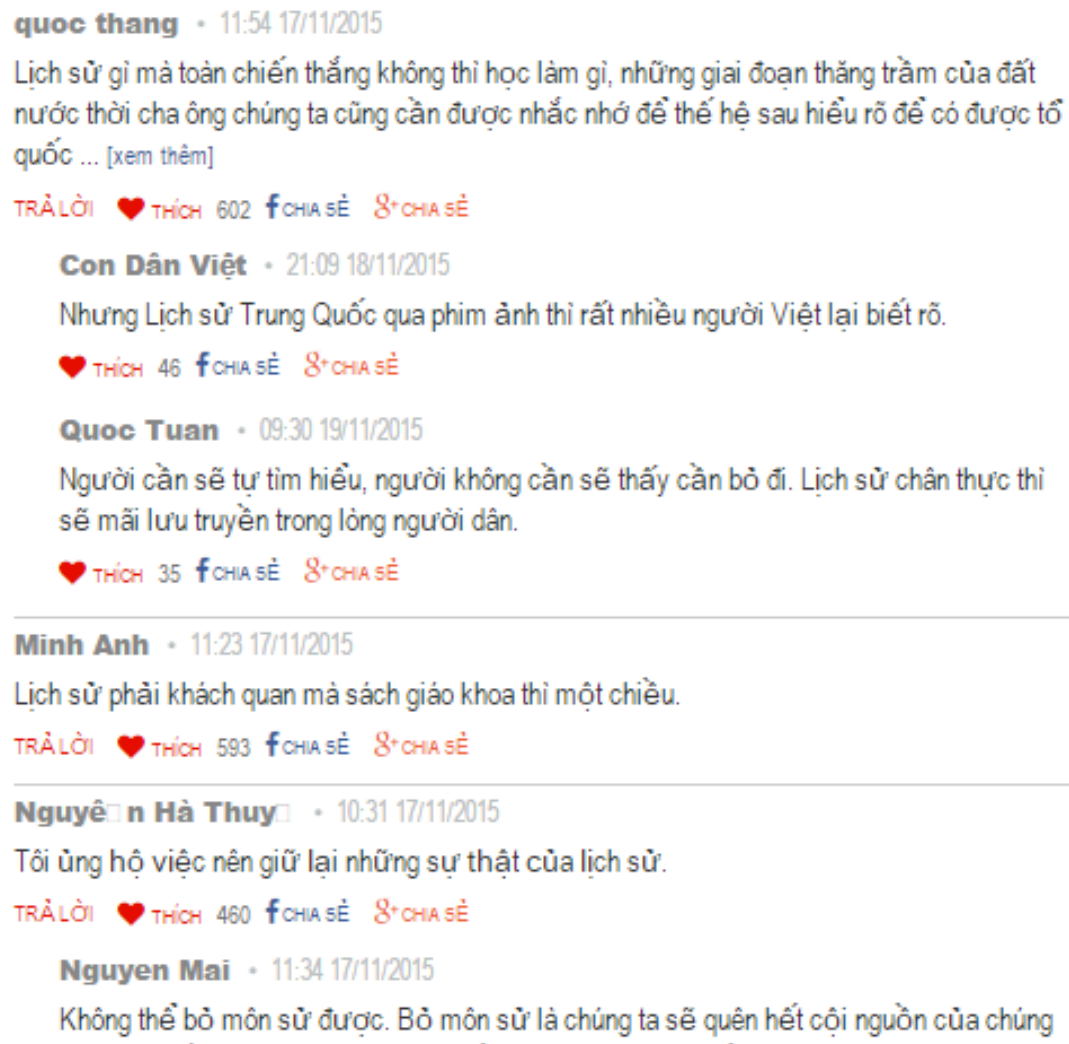

quoc thang: What the point of learning only the victories in history, we also need to learn the ups and downs of our father's country to remind the next generation to understand how we created a unified nation like today, how many generations have fought and sacrificed. Con Dân Việt: But people know much about Chinese history through TV series.

Quoc Tuan: People who are interested in history will read about history, people who aren't will not. But true history will live forever in the heart of our people.

Minh Anh: History is supposed to be impartial but the history book is very biased

Nguyễn Hà Thụy: I support keeping historical truth.

Nguyen Mai: We can't remove history as a subject in school. Losing history means losing our origin.

(Source: Tuoi Tre electronic newspaper, image captured on June 15th, 2017) [20]

Image 1. Readers' opinions on the article "Who will answer for the Vietnamese people this bitter question?"

Reader "Quoc thang" comment received more than 600 likes, this comment received even more likes than an article. The opinions of readers differ in many ways, there are thoughtful arguments and potential solutions.

quoc thang: What the point of learning only the victories in history, we also need to learn the ups and downs of our father's country to remind the next generation to understand how we created a unified nation like today, how many generations have fought and sacrificed.

Minh Anh: History is supposed to be impartial but the history book is very biased.

Nguyễn Hà Thuỵ: I support keeping historical truth.

Viet Nguyen: The way history is taught in school is scaring off students. That's what killing history. It is not conveyed to the students through the sensible and integrated way.

Phụng: History is made of things in the past: culture, arts, customs, ... not just limited to battles. History records the most glorious values for generations to preserve and promote. I see that history textbooks only concern with military 
campaigns against foreign invaders, especially the modern section. Are Vietnamese people only capable of fighting? History lovers are fed up with the textbook.

The readers' comment section below the article becomes a noticeable part of the article. It is possible to call the direct comments to the article as Level 1 discussions. Discussions made from multiple replies to a comment are called Level 2 discussions.

The readers' interaction with the article is about the discussion of the issue that the article poses, extending the issue, or suggesting a solution. In addition, readers can interact with each other by responding to comments from previous readers. In the above example, reader "Con Dân Việt" and "Quoc Tuan" responded to the comment of the reader "Quoc thang" because of new issues in the comment section. However, the interaction between readers is not clear; the number of readers interacting with each other is still small.

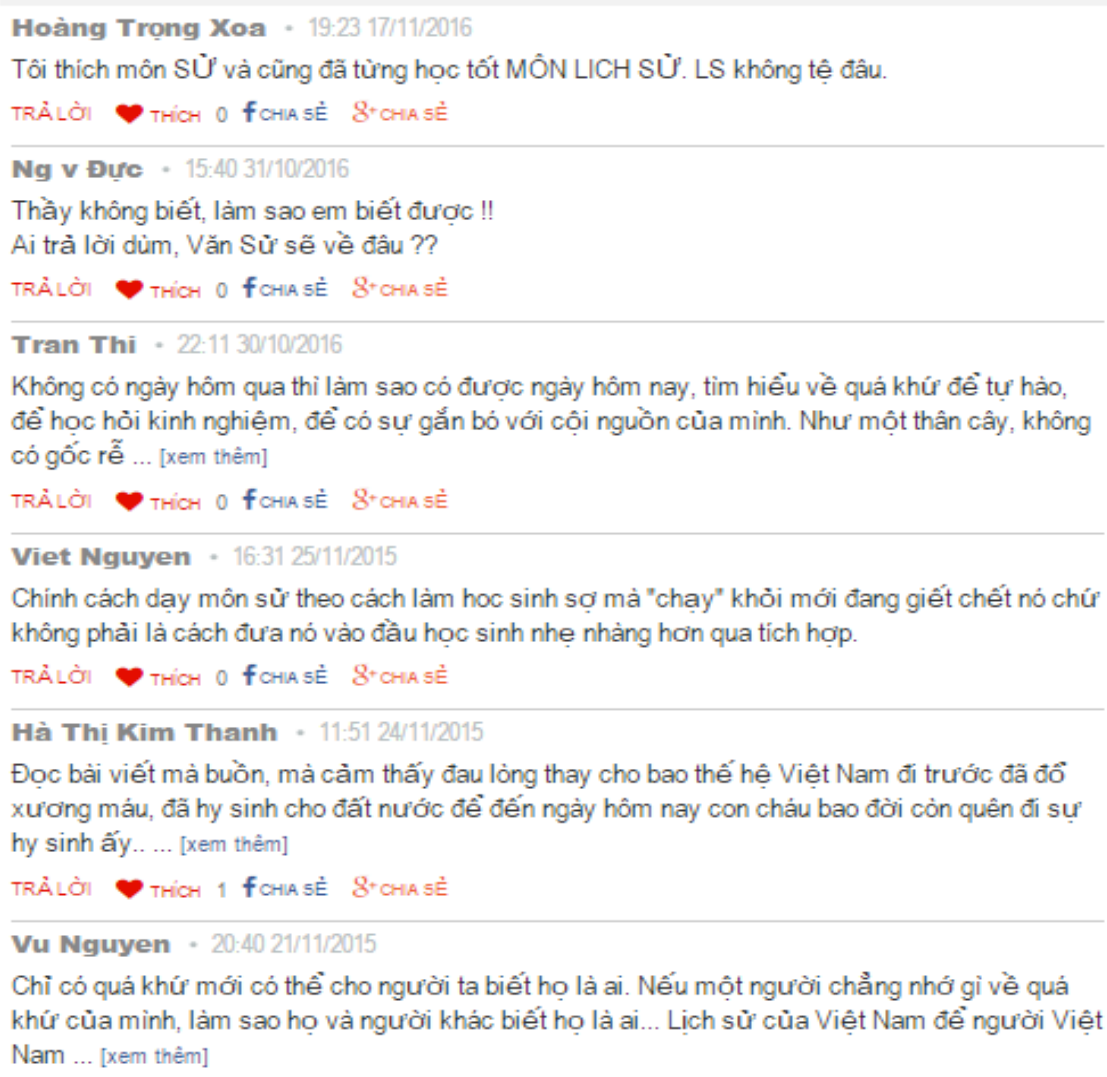

Hoàng Trọng Xoa: I like history and used to excel at it. History is not bad at all.

Ng v Đực: Even the teachers don’t know, you could us student know the answer!! Who will answer, where will subjects like Literature and History go??

Tran Thi: The present will not exist without the past, study about the past to learn, to feel proud, to feel attached to our origins. A tree without its roots...[see more]

Viet Nguyen: The way history is taught in school is scaring off students, that's what killing history. It is not conveyed to the students through the sensible and integrated way.

Hà Thị Kim Thanh: I feel so sad after reading this, feel sad for all previous generations who shed blood for our country only to be forgotten by their children... [see more]

Vu Nguyen: Only the past cant tell people who they really are. If they don't know about their past, how can they and other people know themselves...Our history is for our people....[see more]

(Source: Tuoi Tre electronic newspaper, image captured on June 15th, 2017)[20]

Image 2. Prolonged time period between readers' comment

Time of comment is an important element in the study of the discussion in the public sphere of the electronic newspaper. Tuoi Tre newspaper has no time limit for readers' comments. Although the article "Who will answer for the Vietnamese people this bitter question?" by author Da Ngan was posted on November 17, 2015, there were new comments on November 17, 2016.

Readers may use aliases to comment: người dân, người đọc, con dân, tương ớt or half-western names like Tony $\mathrm{Vu}$, Martin Dinh ... 


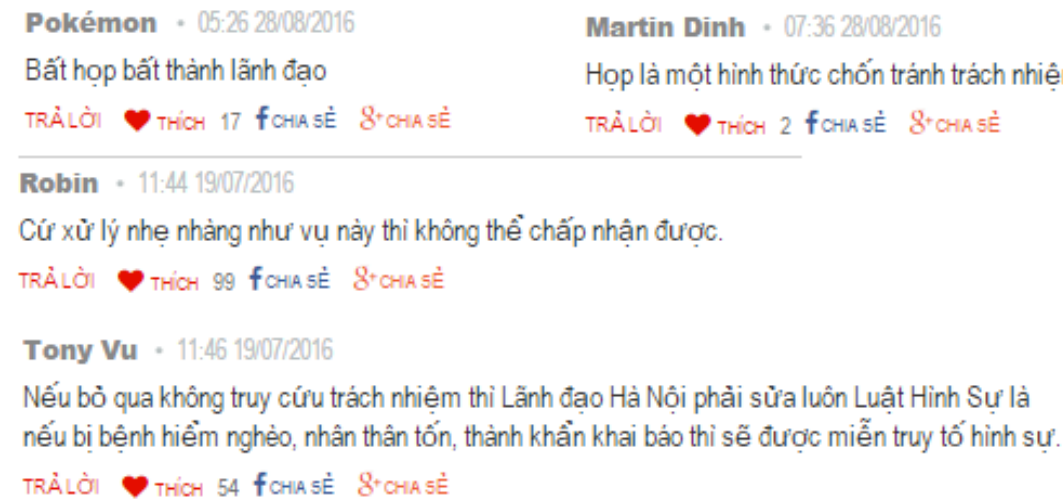

Pokemon: Politicians often go hand in hand with meetings Martin Dinh: Meeting is just a way to avoid responsibility

Robin: We can't accept just slap-on-the-wrist kind of punishment

Tony Vu: if we drop this case then Hanoi leaders will have to amend the Criminal Code that if the defendant has terminal disease, has good profile and confessed faithfully to their crimes, they will be exempted from prosecution

(Source: Tuoi Tre electronic newspaper, image captured on June 15th, 2017) [20]

Image 3. Readers using aliases to comments

If we assume that the number of likes is a positive feedback and indicates a supportive attitude, there are readers' opinions that received more support than the opinion of the author of the article. The article "Sick about the appointment of cadres" by Le Kien published on October 3, 2015, received 211 likes, 37 comments.

Le Kien expressed his opinion on the fact that many children or relatives of officials are appointed to important positions in the government, the author said that if they have a good education and higher degree then they are "absolutely worthy". However, there must be a solution for those who are worthy to work and avoid suspicion.

The total number of 37 comments compared to the average of 12 comments indicated that the article received extensive discussion from readers. Reader "chán" commented: "It's all for nothing, they will wait for the public to forget then the thing will go back to the old way. My experience for decades“, and received 251 replies. From this, we can deduce that the reader's comment receives more support than the article. Nevertheless, the author's article has fulfilled its role in stimulating discussion among readers. Many opinions are given, readers discussed with each other and expressed the honest opinion. The solutions that readers offered are feasible. The discussion process between readers opened more problems, beyond the scope of the original article.

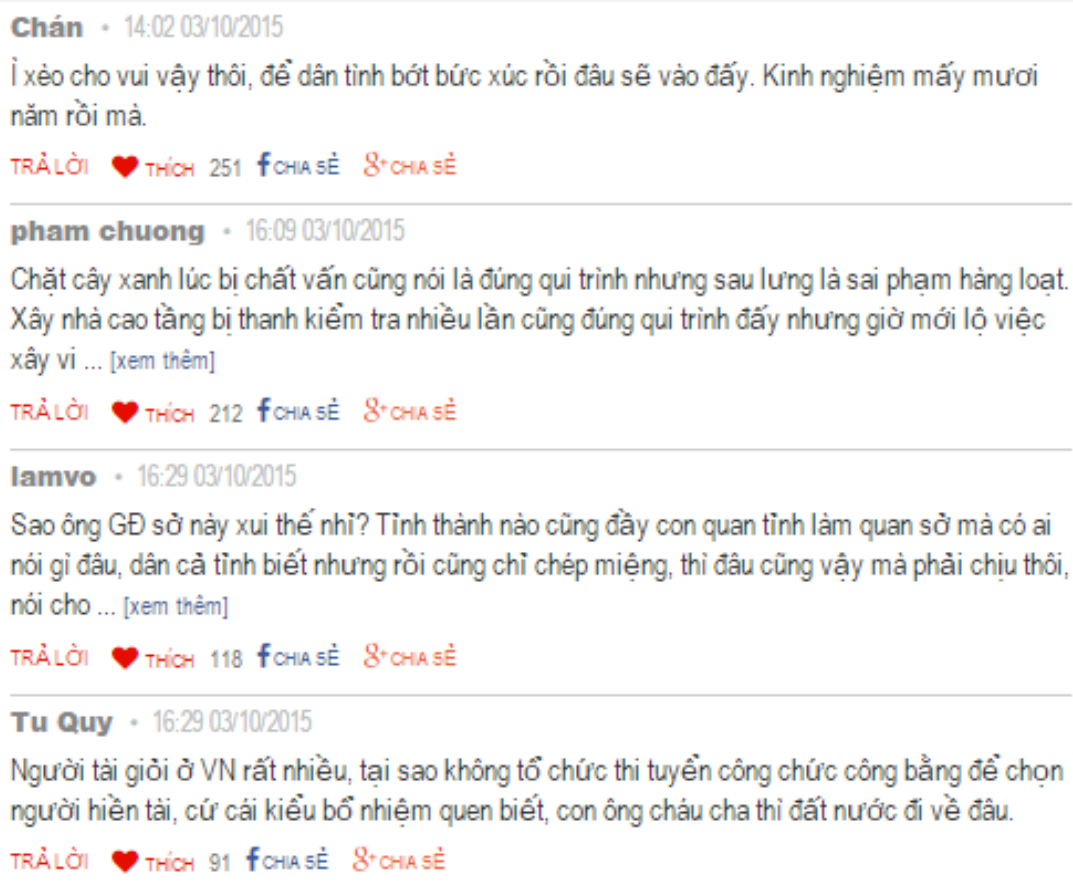


Chán: It's all for nothing, they will wait for the public to forget then the thing will go back to the old way. My experience for decades Pham Chuong: When they were questioned about cutting down trees, they always answered everything is "according to procedure" but behind that are numerous violations. And building skyscrapers also underwent numerous inspections which went "according to procedure" but now they're revealed to violate...[see more]

Lam Vo: Why is this Department Chief so unlucky? There are plenty of relatives and children of high-ranking officials holding offices in every province, the people know but have to accept it since it's the same everywhere, no need to talk...[see more]

Tu Quy: There are many talented people in Vietnam, why don't we hold fair examination to choose the best, where will our country go if the leaders keep appointing their relatives and friends?

(Source: Tuoi Tre electronic newspaper, image captured on June 15th, 2017) [20]

Image 4. Readers' opinion received more likes than the article

\section{Trương Tiến Hāi · 13:36 03/10/2015}

Tại sao lại xì xào chuyện ấy nhĩ, nếu người ta có tài năng và phẩm chất thì bổ nhiệm họ vào chức vụ phù hợp lúc 25 tuôi hay 30 tuôi có gì là khác nhau. Tôi còn nhớ năm 2014 ờ Thụy Điển, Chính phủ đã bổ nhiệm một Nữ Bộ trưởng Giáo dục khi bà mới 27 tuôii. năm nay Nữ Bộ trưởng Giáo dục Thuy Điển bước vào tuôi 28 , vẫn tại chức và xinh đẹp như hoa hậu. Nữ Bộ trưởng Giáo dục Thụy Điển Aida Hadzialic là biểu tượng của sức trè, bỉnh đẳng giới tính và cơ hội cho mọi dân tộc và tôn giáo ờ nước này.

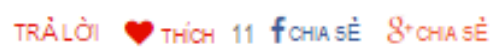

Trần Công Tâm · 14:54 03/10/2015

Bạn dẫn chứng đửng nhưng chưa đủ, đưng là nữ Bộ trưởng Giáo dục Thụy Điển tuôi trè, taii cao và xinh đẹp, chì có điều chính là vì bà được Chính phủ Thụy Điển bổ nhiệm vì có tài năng [xem thêm]

Thich 79 fohiasé 8+chiasé

Ho Van - 20:23 03/10/2015

Sẽ chẳng có ai xì xào nếu chuyện bổ nhiệm một cán bộ tài năng trè tuôi vào vị trí lãnh đạo cao là một hiện tượng phổ biến trong xã hội. Đằng này cà tỉnh chỉ có một mình anh ây được [xem thêm]

- thíar 38 f Chíasé gramiasé

Cú - 17:2503/10/2015

Chăng lẽ cà tình chì có mỗi anh ấy là có tài và phẩm chất?

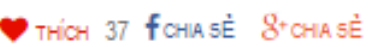

Luân · 15:26 03/10/2015

Sao lại so sánh khập khiễng thế này được.

тнісан 27 fohiasé gromasé

Trương Tiến Hải: Why is there such a fuss about this? If they truly have talents then appointing them to high positions at the age of 25
or 30 is fine. I remembered that in 2014 , the Sweden Government appointed the Minister for Upper Secondary School, Adult
Education, and Training when she was only 27 years old. She is 28 now, still holds her position and remains beautiful as a beauty
queen. Minister Aida Hadzialic is a symbol of youth, gender equality and opportunity for every ethnic and religious group of Sweden.
Trần Công Tâm: Your example is right but not enough, it's true that the Sweden Minister is young, talented and beautiful, however,
the Swedish Government appointed her for her talents.
Ho Van: No one would talk about appointing a young and talented individual into high position is a common thing in society. But in
this case, apparently, only him gets such opportunity in the whole province.
Cú: As if only this guy has talents in the whole province
Luân: What an unparalleled comparison

(Source: Tuoi Tre electronic newspaper, image captured on June 15th, 2017) [20]

Image 5. Readers' discussion extends beyond the scope of the original article 


\section{Conclusions}

From the survey result, it is possible to draw some features of the discussion in the public sphere of the electronic newspaper through Tuoi Tre Online (News and Opinions column).

The first point is that the online discussion process in the electronic newspaper Tuoi Tre Online contains the characteristics of public discussion as we presented at the beginning of this paper with these basic features:

First, though it is essentially a "virtual sphere" with individuals participating through nicknames, most of these nicknames are aliases or unclear, but the participants commenting on the public sphere of electronic newspaper show real characteristics with high discussion rate in fields such as politic, society, and economy.

Second, on the public sphere of electronic newspaper (and the Internet-based environment in general), individuals participate in the discussion process with invested personal perspective as shown through comment tendency that emphasizes personal opinion, storytelling or personal experience...

Third, although politic, society, and economy are the three areas which the public shows the most interest in, the public is cautious when discussing political issues due to its "sensitive" nature. In addition, opinion leaders tend to control discussions to eliminate "unethical", "immoral" views or ideas that contradict state ideology. Thus, the reader has no right to decide whether his opinion is available to the public or not. Moreover, readers can leave their comments on the article through simple steps, this is not limited. But that does not mean that readers have the right to participate in discussions. Because if the reader's opinion is not available to the public, it also means that this opinion is not presented. When the point of discussion is not given, the discussion process does not take place. Asking for written comments in Vietnamese is one of the basic rules that Tuoi Tre Online presents when readers want to comment. Comments that do not meet this requirement will not appear publicly at the end of the article.

The second point is that there are several levels of discussion in the public sphere of the electronic newspaper. The first level is the original discussion (level 1), which is the direct discussion of the content of the article. The second level is the secondary discussion (level 2), which is the discussion of the content that an earlier discussion has raised. This diversity makes the discussions in the public sphere of the electronic newspaper more open in terms of both content and discussion space. Noticeably, in some cases, secondary discussions received more support than the original discussion.

The third point is that discussions in the public sphere of the electronic newspaper are not focused on the content and time of discussion. Thus, scattering and disruption in the discussion process reduce the effectiveness of the discussion, the majority of issues are set up or expanded but fail to reach a final solution. In addition, the disruption of the discussion process among the participants will make the discussion process slower. The discussion process in the electronic newspaper is not time-limited, readers can join in discussions on an issue discussed a few hours, days, weeks, months, even years ago. This opens up different perspectives and explores new issues. This is hard to do with discussions in real space.

The fourth point is that the discussion in the public sphere of Vietnam electronic newspaper today is not truly a platform for everyone to discuss. Everyone has free access to the website tuoitre.vn, but not everyone can participate in the discussion because the requirement of the internet and electronic newspapers requires skills to set up connection, level of education and awareness, ability to analyze and argue. People participating in online discussion are often capable of analyzing and assessing issues with vested interest in social and political issues. Thus, the disadvantaged readers in terms of education, living space, income such as people in remote and poor areas... do not have the opportunity to participate in the discussion process in the public sphere of the electronic newspaper.

The fifth point is that the control of information on the electronic newspaper interface of the editorial office creates the uniqueness of the public sphere of electronic newspaper compared with the public spheres on other types using the same online platform. Social network is a good example. On social networks, participants engage in a relatively liberal discussion process. Posting of articles, discussion topics are not controlled by an editorial department like that in the electronic newspaper. The process of discussion, too, is not subjected to deliberate screening. This difference raises two contrasting problems. On the one hand, the control of electronic newspapers helps the discussion topic to be more focused, avoid distracting ideas or even unethical or immoral topics. Theoretically, the concentration of discussions in the editorial staff's direction will produce better discussion results. On the other hand, this control creates certain barriers to the freedom of speech of the topics. Of course, editorial control is irreversible, as the editorial board publishes articles or publicly discusses that they are responsible before the law for the content of the article as well as the discussions

\section{REFERENCES}

[1] Papacharissi, Zizi. 2002. The virtual sphere: The internet as a public sphere, SAGE publications, London, Thousand Oak, CA and New Delhi, Vol. 4, P.9-27.

[2] Papacharissi, Zizi. 2010. A Private Sphere: Democracy in a Digital Age. Cambridge: Polity Press.

[3] Jones, S.G. 1997. 'The internet and its Social Landscape', in S.G. Jones (ed.) Virtual Culture: Identity and 
Communication in Cybersociety, pp.7. Thousand Oaks, CA: Sage

[4] McChesney, R. 1995. "The Internet and US Communication Policy-Making in Historical and Critical Perspective". Journal of Computer-Mediated Communication Volume 4, Issue 1, P.98-124.

[5] Poster, M. 1995. The internet as a Public Sphere?, Wired 3 (1): 209.

[6] Carey, J. 1995. 'The press, Public Opinion, and Public Discourse', in T. Glasser and C. Salmon (eds) Public Opinion and the Communication of Consent, pp.373, New York: Guilford

[7] Fallows, J. 1996. "Why Americans Hate the Media". The Atlantic Monthly (February) 277 (2): 454.

[8] Trần Hữu Quang. 2008. "Truyền thông đại chúng trong xã hội hiện đại". Thời báo Kinh tế Sài Gòn số $7 \& 8$, Xuân Mậu Tý, 7/2/2008. Trang 16-19/ Trần Hữu Quang. 2008. "Mass media in modern society". Saigon Times issue no.7\&8, Mậu Tý Tet Festival, 07/2/2008. Page 16-19.

[9] Nguyễn Quý Thanh, Trịnh Ngọc Hà. 2009. "Không gian bán công cộng và sự hình thành dư luận xã hội: nghiên cứu trường hợp quán cà phê ở Hà Nội". Tạp chí Xã hộ hoc 2: Trang.72-81./ Nguyễn Quý Thanh, Trịnh Ngọc Hà. 2009. "Semi-public sphere and the formation of public opinion: The case study of coffee shops in Hanoi". Journal of Sociology 2: Page 72-81.

[10] Phan Văn Kiền. 2015. Tính đặc thù của 'không gian công' trên báo điện tử, 25 Năm nghiên cứu và đào tạo báo chí truyền thông. Hà Nội: Nhà xuất bản Đại học Quốc gia Hà Nội./Phan Văn Kiền.2015. "The feature of "public sphere" on electronic newspaper, 25 years of training and research on journalism and media. Hà Nội: VNU Press.

[11] Nguyễn Thị Thuý Hằng, Vũ Thi Minh Thắng. 2015. "Sự hình thành không gian công ở Việt Nam trước năm 1945: Nghiên cứu dưới góc độ báo chí học, chính trị học và lịch sử". Kỷ yếu Hội nghị khoa học cán bộ trẻ và học viên sau đại học. Hà Nội: Nhà xuất bản Đại học Quốc gia Hà Nội, Tr.298-310./ Nguyễn Thị Thúy Hằng, Vũ Thị Minh Thắng. 2015. "The establishment of the public sphere in Vietnam before 1945: Research under the purview of journalism, political science and history". Proceeding of Scientific
Conference of young researchers and post-graduate students. Hanoi: VNU Press, page 298-310.

[12] Kant, Immanuel. 2006a. "An Answer to the Question: What Is Enlightenment?" [1784], in Immanuel Kant, "Toward Perpetual Peace" and Other Writings on Politics, Peace, and History, Yale University Press.

[13] Kant, Immanuel. 2006b. "The Contest of the Faculties, Part Two. The Contest of the Faculty of Philosophy with the Faculty of Law" [1798], in Immanuel Kant, "Toward Perpetual Peace" and Other Writings on Politics, Peace, and History

[14] Habermas, Jurgen. 1980. Discourse Ethics: Notes on Philosophical Justification. Moral Consciousness and Communicative Action. Trans. Christian Lenhart and Shierry Weber Nicholson. Cambridge: MIT Press.

[15] Đỗ Văn Quân. 2012. Phản biện xã hội qua báo chi ở Việt Nam hiện nay. Luận án Tiến sĩ Xã hội học, Học viên Chính trị Quốc gia Hồ Chí Minh./ Đỗ Văn Quân.2012. Social review through newspapers in Vietnam nowadays. Doctoral thesis on Sociology, Ho Chi Minh National Academy of Politic.

[16] Nguyễn Thị Bích Thủy. 2012. Chơ nông thôn, mọt không gian công cộng cho sụ hình thành du luận xã hội (nghiên cưu truòng hơp chơ Mai Trang và chơ Mộc, huyện Nghi Lộc, tỉnh Nghệ An). Luận văn thạc sĩ Xã hội học, Trường Đại học Khoa học Xã hội và Nhân văn, ĐHQGHN./ Nguyễn Thị Bích Thủy. 2012. "Rural market: a public sphere for the formation of public opinion (Case study of Mai Trang market and Mồc market, Nghi Lộc District, Nghê An Province). Master thesis of Sociology, University of Social Sciences and Humanities, VNU.

[17] Dewey, J. 1927. The Public and it Problems. New York: Holt.

[18] Habermas, Jurgen (1962 trans-1989) The Structural Transformation of the Public Sphere: An Inquiry into a category of Bourgeois Society, Polity, Cambridge

[19] Daniel Lerne (1957), Communication systems and social systems. A statistical exploration in history and policy, Journal of Systems Research and Behavioral Science, Volum2, Issue 4, P.266-257.

[20] http://tuoitre.vn (Accessed 4/5/2016)

${ }^{*}$ The article is the result of the doctoral dissertation: "Social criticism and orienting social opinion role of Vietnam electronic newspaper." 